\title{
Bat richness (Mammalia: Chiroptera) in an area of montane Atlantic Forest in the Serra da Mantiqueira, state of Minas Gerais, southeast Brazil
}

\author{
Bruna da Silva Xavier ${ }^{I}$, William Douglas Carvalho ${ }^{2,3 *}$, Daniela Dias ${ }^{4}$, Lorena de Oliveira Tabosa ${ }^{\text {, }}$, Carlos \\ Eduardo Lopes Santos ${ }^{I}$ \& Carlos Eduardo Lustosa Esbérard ${ }^{I}$ \\ ${ }^{1}$ Universidade Federal Rural do Rio de Janeiro, Instituto de Biologia, Departamento de Biologia Animal, \\ Laboratório de Diversidade de Morcegos, CP 74507, 23890-000, Seropédica, RJ, Brasil \\ ${ }^{2}$ Universidade do Amapá, Programa de Pós-graduação em Biodiversidade Tropical, Rod. Juscelino \\ Kubitscheck, S/N, AP 68903-419, Macapá, Brasil \\ ${ }^{3}$ Universidade Federal do Amapá, Departamento de Meio Ambiente e Desenvolvimento, Laboratório de \\ Ecologia, AP 68903-419, Macapá, Brasil \\ ${ }^{4}$ Fundação Oswaldo Cruz, Laboratório de Biologia e Parasitologia de Mamíferos Silvestres Reservatórios, \\ 21040-900, Rio de Janeiro, RJ, Brasil \\ *Corresponding author: William Douglas de Carvalho, e-mail: wilruoca@hotmail.com
}

XAVIER, B. S., CARVALHO, W. D., DIAS, D., TABOSA, L. O., SANTOS, C. E. L., ESBÉRARD, C. E. L. Bat richness (Mammalia: Chiroptera) in an area of montane Atlantic Forest in the Serra da Mantiqueira, state of Minas Gerais, southeast Brazil. Biota Neotropica. 18(2): e20170496. http://dx.doi.org/10.1590/1676-0611BN-2017-0496

\begin{abstract}
In recent years there has been an increase in research interest in remnants of Atlantic Forest above $500 \mathrm{~m}$ a.s.1., such as in the Serra da Mantiqueira, which is considered a priority area for conservation. The chiropterofauna of the Serra da Mantiqueira remains relatively under-studied, and here we present a list of bat species from the "Reserva Particular do Patrimônio Natural (RPPN) Cachoeira do Tombo", a private conservation unit located in an area of montane Atlantic Forest in the Serra da Mantiqueira. Bats were captured with mist nets along trails and near a diurnal roost. A total of 498 individuals of 19 bat species belonging to the families Phyllostomidae, Vespertilionidae and Molossidae were captured. Phyllostomidae were captured only along the trails, Molossidae were captured only in the diurnal roost and Vespertilionidae were captured in both. The species accumulation curves did not show stabilizing trends. However, $80 \%$ of the expected richness was sampled and the species richness of bats found is similar to other studies previously carried out in the region. In contrast to other inventories carried out in the Atlantic Forest, Desmodus rotundus was the species most frequently captured along the trails. A large number of individuals of Molossus aztecus sheltering in man-made structures were caught, constituting an unusual event. Additionally, here we report cohabitation of this species with Molossus molossus for the first time. Our results show that this area, which appears on the map of environmental conflicts for the state of Minas Gerais, has a rich chiropterofauna and also further corroborate the importance of using mist-nets at roosts to increase the probability of capturing the richness and abundance of insectivorous bats present in the area.
\end{abstract}

Keywords: Biodiversity, high elevation, sampling, Phyllostomidae, Molossidae, Verspertilionidae.

\section{Riqueza de morcegos (Mammalia: Chiroptera) em uma área de Floresta Atlântica montana na Serra da Mantiqueira, estado de Minas Gerais, sudeste do Brasil}

Resumo: Nos últimos anos houve um aumento no interesse em pesquisas em remanescentes de Floresta Atlântica acima de $500 \mathrm{~m}$ de altitude, como na Serra da Mantiqueira, a qual é considerada área prioritária para a conservação. A fauna de quirópteros na Serra da Mantiqueira ainda permanece relativamente pouco estudada, e aqui nós apresentamos uma lista de espécies de morcegos da Reserva Particular do Patrimônio Natural (RPPN) Cachoeira do Tombo, uma unidade de conservação privada localizada em área de Floresta Atlântica Montana na Serra da Mantiqueira. Os morcegos foram capturados com redes de neblina ao longo de trilhas e junto de um abrigo diurno. Um total de 498 indivíduos de 19 espécies de morcegos pertencentes às famílias Phyllostomidae, Vespertilionidae e Molossidae foram capturados. Phyllostomidae foram capturados somente em trilhas, Molossidae 
no abrigo diurno e Vespertilionidae em ambos. As curvas de acumulação de espécies não mostraram tendência de estabilização. No entanto, $80 \%$ da riqueza esperada foi amostrada e a riqueza de espécies encontrada foi similar a outros estudos previamente conduzidos na região. Diferente de outros inventários realizados na Mata Atlântica, Desmodus rotundus foi a espécie mais frequentemente capturada ao longo das trilhas. Um grande número de indivíduos de Molossus aztecus foi encontrado se abrigando em abrigo artificial, o que constitui um evento pouco usual. Adicionalmente, a coabitação dessa espécie com Molossus molossus é reportada aqui pela primeira vez. Os resultados mostram que essa área, que está inserida no mapa de conflitos ambientais do estado de Minas Gerais, possui uma rica chiropterofauna e corrobora a importância de usar redes de neblina em abrigos para aumentar a probabilidade de capturar a riqueza e abundância de morcegos insetívoros presentes na área.

Palavras-chave: Biodiversidade, altitude elevada, inventário, Phyllostomidae, Molossidae, Verspertilionidae.

\section{Introduction}

The southeast region of Brazil is considered to be the most wellstudied of the country in terms of Chiroptera (Bergallo et al. 2003, Brito et al. 2009), owing in large part to a higher concentration of research institutes compared with other regions (Brito et al. 2009). Although most of studies on Chiroptera in the region have been conducted at elevations below $500 \mathrm{~m}$ a.s.l., in recent years there has been an increase in research interest in remnants of Atlantic Forest between 500 and 1,500 m a.s.1. (e.g., Dias et al. 2008, Modesto et al. 2008, Delciellos et al. 2012, Luz et al. 2013, Moras et al. 2013, Martins et al. 2015).

Among the states of the southeast of Brazil, Minas Gerais is of particular conservation importance as it encompasses three Brazilian biomes (Caatinga, Cerrado and Atlantic Forest, with the latter two considered conservation hotspots threatened by constant anthropogenic pressure) (Myers et al. 2000, Mittermeier et al. 2005, Tavares et al. 2010). The current list of bats for Minas Gerais consists of 85 species (Tavares et al. 2010, Garbino 2011, Gregorin \& Loureiro 2011, Gregorin et al. 2011, Carvalho et al. 2013, Dias et al. 2015, Gregorin et al. 2015). However, the state has many areas which remain under- or un-sampled (Tavares et al. 2010), and therefore further studies are necessary, and indeed are highly likely to report new species for the state.

The largest remnants of Atlantic Forest are located in the border region between Minas Gerais, Rio de Janeiro and São Paulo (Costa et al. 2009, Ribeiro et al. 2009). This region is further characterised by areas of transition between Cerrado and Atlantic Forest, such as those found in the foothills of the Serra da Mantiqueira in Minas Gerais (IBGE 2012). Owing to the presence of these remnants and transition zones, the Serra da Mantiqueira is considered a priority area for conservation, being indicated for implementation of protected areas to safeguard native habitat remnants (Costa et al. 1998, Drummond et al. 2005). While some species lists and local occurrences of bats have recently been published for the region (e.g., Carvalho et al. 2013, Luz et al. 2013, Nobre et al. 2013a, Nobre et al. 2013b, Dias et al. 2015, Martins et al. 2015), the chiropterofauna still remains relatively under-studied.

This study presents a list of bat species mist-netted in the private conservation reserve "Reserva Particular do Patrimônio Natural (RPPN) Cachoeira do Tombo" (hereafter referred to as the Cachoeira do Tombo RPPN or simply the RPPN). The RPPN is located in an area of montane Atlantic Forest in the Serra da Mantiqueira Environmental Protection Area and within the buffer zone of the Serra do Papagaio State Park. This list contributes to knowledge of chiropterofauna in areas of montane forest, which are frequently neglected in inventories, and in particular to knowledge of the chiropterofauna of the Serra da Mantiqueira.

\section{Material and Methods}

\section{Study area}

The study was conducted in the Cachoeira do Tombo RPPN, located in the municipality of Aiuruoca, state of Minas Gerais (22 00 '23.4”S, $44^{\circ} 36^{\prime} 22.2$ "W; 1,100 m a.s.1.; Figure 1). The reserve has a total area of 12.02 ha and falls within the Atlantic Forest biome, although the surrounding areas include stretches of cerrado and indeed the region is considered to be an ecotone between the Atlantic Forest and Cerrado biomes (RADAM BRASIL 1983). The local climate is classified as a subtropical highland type (Cwb), with mild summers (Sá-Júnior et al. 2012). Temperatures in the hottest month are below $22^{\circ} \mathrm{C}$, the average annual temperature varies between 18 and $19^{\circ} \mathrm{C}$, and the average annual precipitation is in the order of 1,400 mm (Sá-Júnior et al. 2012). December, January and February are the rainiest months, and June, July and August the driest (Scolforo et al. 2002). The RPPN is a Permanent Environmental Protection Area located within the Serra da Mantiqueira Environmental Protection Area and in the buffer zone of the Serra do Papagaio State Park.

\section{Bat captures and data analysis}

Bats were captured along four different trails within the RPPN on 14 nights, though the samples were not simultaneous along all trails, but rather one trail was sampled 11 times, and each of the other trails just once each. The average distance between trails was $346.2 \pm 211 \mathrm{~m}$. A diurnal roost located $150 \mathrm{~m}$ from the edge of the RPPN was also sampled on 14 nights, 10 of which were simultaneous with the sampling on the first trail within the RPPN and four on additional nights. As such, bats were captured during a total of 18 nights between August 2012 and April 2015. The diurnal roost was located in the ceiling space of a chalet which had been abandoned as a result of the presence of the bats. The roof of the chalet consisted of asbestos roof tiles and wooden roof beams, and was lined with pinewood, on top of which a layer of polystyrene had been placed to insulate the interior of the chalet from the heat of the sun.

The bats were caught using mist-nets $(9 \times 2.5 \mathrm{~m})$, set between dusk and midnight at the diurnal roost, and between dusk and dawn along the trails of the RPPN, during different lunar phases (see Esbérard 2007). Sampling effort was calculated by multiplying the number of hours for which the nets were kept open by the area of the nets $\left(\mathrm{m}^{2}\right)$, following Straube \& Bianconi (2002). Adult bats greater than $5 \mathrm{~g}$ were marked with plastic collars individually coded, according to Esbérard \& Daemon (1999). To mark juveniles and adults of species which have a body mass equal to or less than $5 \mathrm{~g}$, "punch-marking" (small holes made in the 

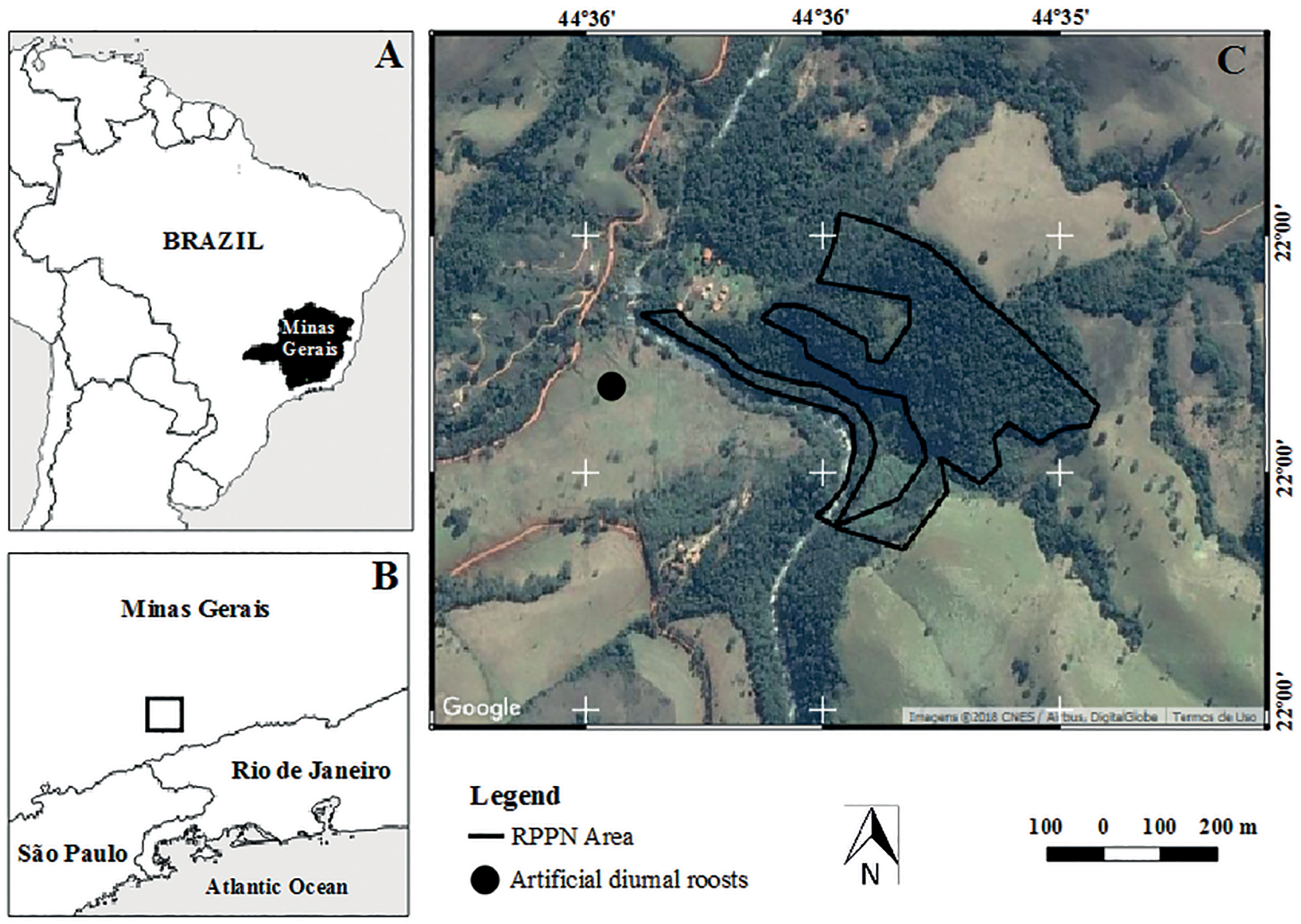

Figure 1. (A) South America with the state of Minas Gerais indicated. (B) States of the southeast of Brazil and the study area highlighted (square). (C) Area of the Cachoeira do Tombo RPPN, in the municipality of Aiuruoca, state of Minas Gerais, Brazil.

dactylo patagium) was used (see Bonaccorso \& Smythe 1972). From 2013 onwards, all juvenile and small-bodied (less than $5 \mathrm{~g}$ ) adult bats were marked with Trevisan ${ }^{\circledR}$ microchips.

The captured animals were preliminarily identified in the field using identification keys and field guides (Reis et al. 2013). Data on length of the forearm, body mass and reproductive state were collected, and most individuals were then released where they were captured. In order to carry out morphological analyses and confirm taxonomic identifications some individuals were collected, prepared as voucher specimens, preserved in spirits, and deposited in the collection of the Bat Diversity Laboratory (LDM - IBAMA process 1755/89), Institute of Biology, Federal Rural University of Rio de Janeiro (Appendix 1). All field procedures were carried out with permission from the "Instituto Chico Mendes para Conservação da Biodiversidade" (ICMBio) (permanent licence for collection granted to C.E.L. Esbérard - number 10356-1, issued on 06/09/2007). The "Instituto Estadual de Florestas-MG" granted permission to carry out the collections within and around the Serra do Papagaio State Park (UC:151/11 - Extension I).

Observed and randomized (using 1,000 randomizations without replacement and a confidence interval of $95 \%$ ) species accumulation curves were plotted for each sampling site - the diurnal roost and the four trails within the RPPN. Expected species richness, considering first-order Jacknife values, was also calculated in order to verify the percentage species richness sampled in each site. All analyses were conducted using the packet "vegan" (Oskanen et al. 2017) in R (R Development core team 2017).

\section{Results}

A total of 498 individuals of 19 bat species belonging to three families (Phyllostomidae, Vespertilionidae and Molossidae) were captured (Table 1). Two-hundred and seventeen individuals of 13 species and 281 individuals of six species were captured along the trails within the RPPN and at the diurnal roost, respectively (Table 1). Sixty-four individuals were re-captured, nine along the trails within the RPPN and 55 at the diurnal roost.

The randomised species accumulation curves for each sampling location seem to show a decrease in the rate of species addition (Figure 2). The total species richness found in the RPPN (including the trails and the diurnal roost) represented $80.1 \%$ of the estimated richness for the RPPN (first-order Jacknife $=23.72$ species; s.d. = 2.52). The species richness found along the trails within the RPPN represented only $77.75 \%$ of the estimated richness (first-order Jacknife $=16.71$ species; s.d. $=2.30$ ). The species richness found at the diurnal roost represented $86.58 \%$ of the estimated richness (first-order Jacknife = 6.93 species; s.d. $=0.93$ ). 
Xavier, B.S. et al.

Table 1. Bats collected between 2012 and 2015 in the Cachoeira do Tombo RPPN, in Aiuruoca, Minas Gerais, including the first captures and the number of re-captures (in brackets). $\mathrm{LC}=$ least concern, $\mathrm{DD}=$ data deficient. * Conservation status according to ICMBio (2014).

\begin{tabular}{|c|c|c|c|c|}
\hline \multirow{2}{*}{$\begin{array}{l}\text { FAMILY } \\
\text { Subfamily } \\
\text { Species } \\
\end{array}$} & \multicolumn{3}{|c|}{ Captures (Recaptures) } & \multirow[t]{2}{*}{ Conservation status* } \\
\hline & Trail & Roost & Total & \\
\hline \multicolumn{5}{|l|}{ Desmodontinae } \\
\hline Desmodus rotundus (É. Geoffroy, 1810) & $83(7)$ & - & $83(7)$ & $\mathrm{LC}$ \\
\hline Anoura geoffroyi Gray, 1838 & 1 & - & 1 & $\mathrm{LC}$ \\
\hline \multicolumn{5}{|l|}{ Phyllostominae } \\
\hline Phyllostomus hastatus (Pallas, 1767) & 1 & - & 1 & $\mathrm{LC}$ \\
\hline Mimon bennettii (Gray, 1838) & 3 & - & 3 & $\mathrm{LC}$ \\
\hline Artibeus fimbriatus Gray, 1838 & 5 & - & 5 & $\mathrm{LC}$ \\
\hline Artibeus lituratus (Olfers, 1818) & 21 & - & 21 & $\mathrm{LC}$ \\
\hline Platyrrhinus lineatus (É. Geoffroy, 1810) & 9 & - & 9 & $\mathrm{LC}$ \\
\hline Sturnira lilium (É. Geoffroy, 1810) & 25 & - & 25 & $\mathrm{LC}$ \\
\hline Vampyressa pusilla (Wagner, 1843) & 1 & - & 1 & $\mathrm{LC}$ \\
\hline \multicolumn{5}{|l|}{ VESPERTILIONIDAE } \\
\hline Eptesicus diminutus Osgood, 1915 & 1 & - & 1 & $\mathrm{LC}$ \\
\hline Eptesicus sp. & - & $133(3)$ & $133(3)$ & - \\
\hline Histiotus velatus (I. Geoffroy, 1824) & - & 2 & 2 & DD \\
\hline Molossus molosssus (Pallas, 1766) & - & $8(10)$ & $8(10)$ & $\mathrm{LC}$ \\
\hline TOTAL & $217(9)$ & $281(55)$ & $498(64)$ & \\
\hline SAMPLING EFFORT $\left(m^{2 *} h\right)$ & $25,625.25$ & $16,027.5$ & $41,652.75$ & \\
\hline
\end{tabular}

Phyllostomidae were captured only along the trails within the RPPN, and at the diurnal roost only species of Vespertilionidae and Molossidae were captured. In contrast, just two species of Vespertilionidae, and no Molossidae were captured along the trails. The most frequently caught species along the trails was Desmodus rotundus with 83 captures ( $16.7 \%$ of the total), followed by Carollia perspicillata with 38 captures $(7.6 \%$ of the total) (Table 1$)$. The captures carried out at the diurnal roost contributed $31.58 \%$ of the richness sampled for the RPPN. The most frequently caught species at the roost was Eptesicus sp. with 133 captures (26.7\% of the total), followed by Molossus aztecus with 124 captures (24.9\% of the total).

\section{Discussion}

Phyllostomidae were only caught in the mist-nets set along the trails within the RPPN. Indeed, this sampling design favours the capture of bats of this family (Kunz \& Parsons 2009). Moreover, insectivorous species are known to be under-sampled by mist-netting (Kalko et al. 2008, Meyer et al. 2011, Marques et al. 2016). In order to increase the sample of such species, it is therefore recommended that other methods be used, such as acoustic recordings (Meyer et al. 2011) or setting of mist-nets above water-bodies, close to diurnal shelters (Lourenço et al. 2010, Costa et al. 2012) or even sampling in the canopy (Gregorin et al. 2017). In the present study, $31.58 \%$ of the total sampled richness was obtained from the samples at the diurnal roost. 

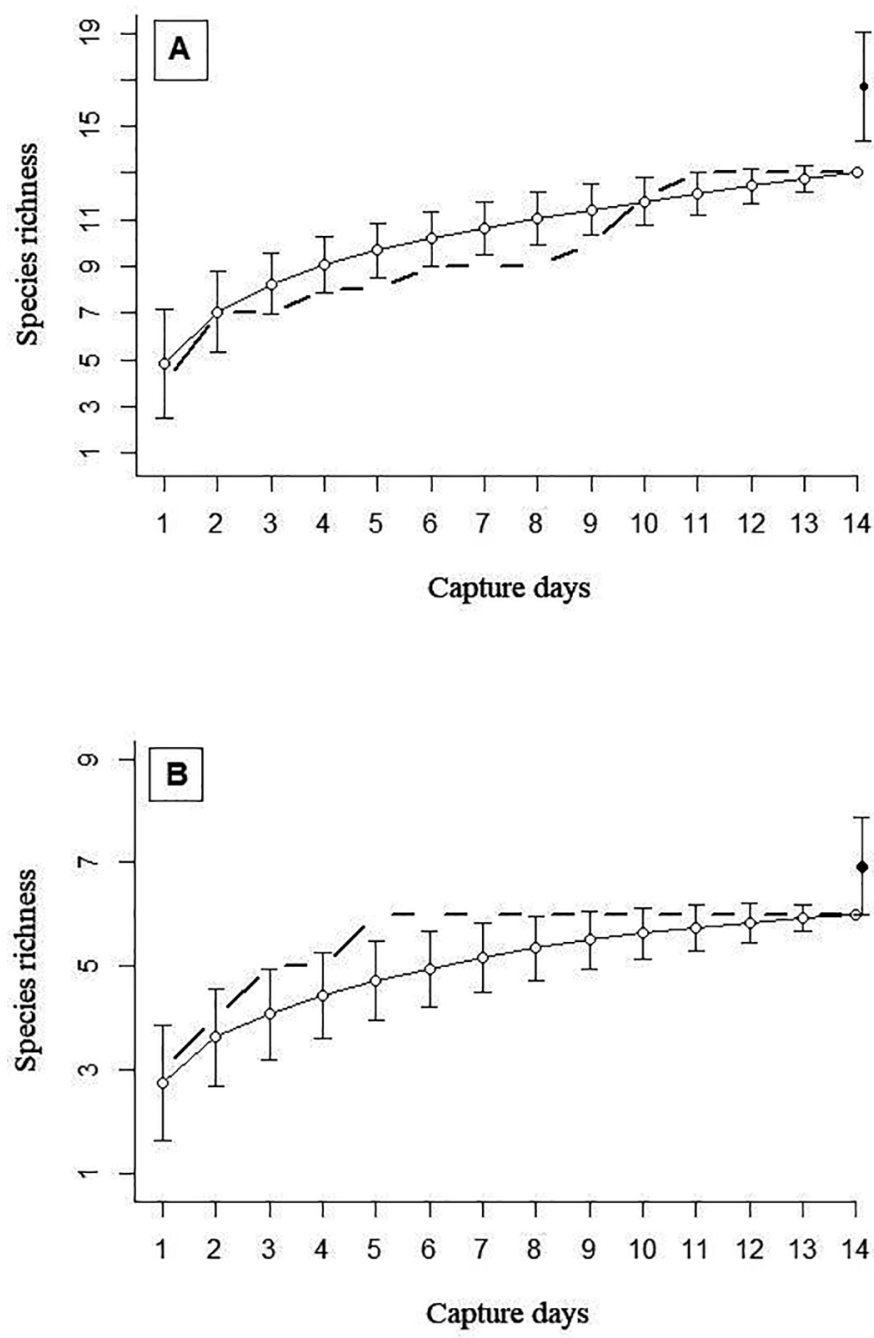

Figure 2. Species accumulation curve for bats captured in the Cachoeira do Tombo RPPN: (A) trails located within the RPPN; (B) diurnal roost located $150 \mathrm{~m}$ from the border of RPPN. The dashed line shows the observed species accumulation curve. The solid line shows the randomized species accumulation curve with the arrows showing the $95 \%$ confidence intervals. The solid circle shows the first-order Jacknife value with the arrows showing the standard deviation.

The species accumulation curves did not show stabilizing trends, however, $80 \%$ of the expected richness was sampled, both along the trails and at the roost. While it has been suggested that the ideal total number of captures to sample richness of bats of the family Phyllostomidae in tropical forests is 1,000 individuals (Bergallo et al. 2003), this number can be considered to be un-realistic and highly dependent upon numerous other factors. For example, differences in species composition, local abundance, habitat types and landscape attributes, as well as local climate, can in large part explain the observed variations in detection and capture of species between localities (Meyer et al. 2011, Stevens 2013). For example, it has been shown that along an altitudinal gradient the collection curve stabilizes at higher altitudes when the total number of captures is less than 1,000 individuals, because the climatic conditions are more extreme (i.e. colder temperatures and lower resource availability) and species richness and local abundance are lower (Carvalho 2015). However, a greater sampling effort is still required for the Cachoeira do Tombo RPPN, in order to better characterise the bat fauna of the region.

The species richness of bats found in the present study is, however, similar to that found in other studies carried out in the Serra da Mantiqueira. For example, in a mountainous area between 870 and $1,040 \mathrm{~m}$ a.s.l. of the Serra Negra (state of Minas Gerais) with rocky outcrops and pastures, 19 species were registered during 70 nights of sampling with mist-nets set for between 6 and 8 hours after nightfall (Nobre et al. 2013a). In dense, high-montane rainforest, boulder fields and high altitude cerrado (average altitude of 1,500 m) of the Ibitipoca State Park, 17 species were registered in 68 nights of sampling using mist-nets open for 6 hours in areas of forest, clearings and at roosts (mainly caves) (Nobre et al. 2013b). In another area of montane forest in the Visconde de Mauá region of the state of Rio de Janeiro, 13 species were registered after seven nights of sampling with mist-nets set for 12.5 hours per night (Luz et al. 2013). In the Itatiaia National Park, in areas between 500 and 2,500 $\mathrm{m}$ a.s.1., 22 species were captured in 32 nights of mist-netting for 6 hours per night (Martins et al. 2015). The total species richness sampled in the RPPN in this present study represents $27.94 \%$ of the species already reported for the Atlantic Forest of Minas Gerais (68 species; see Tavares et al. 2010, Garbino 2011, Gregorin \& Loureiro 2011, Gregorin et al. 2011, Carvalho et al. 2013, Dias et al. 2015, Gregorin et al. 2015).

Among Phyllostomidae, D. rotundus was the species most frequently captured along the trails of the RPPN. This result differs from inventories carried out in the Atlantic Forest, where captures of $D$. rotundus generally represent $2 \%$ or less of the total captures, even in areas with large numbers of caves (see Costa \& Esbérard 2011). This may be explained by several factors, including the presence of cattle for dairy and beef in the adjacent areas, and by the formation of large colonies owing to the high number of rocky outcrops, with natural caves, in the region. Indeed, D. rotundus is usually present in inventories carried out in grottos and caves (Trajano 1985, Campanha \& Fowler 1993, Guimarães 2014) and close to human settlements with high densities of livestock (Costa \& Esbérard 2011). In one cave, located $400 \mathrm{~m}$ from the edge of the RPPN, it was possible to observe around 600 individuals of $D$. rotundus (personal observation). The second most commonly sampled species of Phyllostomidae was $C$. perspicillata, a species which is frequently caught in inventories carried out in the Atlantic Forest, especially in areas with a high density of Piper spp., as is the case in the RPPN (personal observation). Fruits of Piper spp. constitute the preferred food item in the diet of $C$. perspicillata in periods of high availability of the resource (Andrade et al. 2013).

The capture of a large number of individuals of the species $M$. aztecus sheltering in man-made structures remains an unusual event (Gregorin et al. 2011) and furthermore, cohabitation of this species with M. molossus had not previously been reported. Indeed, this study represents the fifth report of M. aztecus for Minas Gerais (Gregorin et al. 2011, Oliveira 2013, Loureiro 2014, Gregorin et al. 2017). In order to verify the occurrence of $M$. aztecus in the other states of the region and improve knowledge of the biology and distribution of the species, we recommend a reassessment of the $M$. molossus specimens obtained in studies in the southeast and held in zoological collections. 
The mosaic of the Serra da Mantiqueira has been altered since 2008 and continues to be threatened by the possible construction of hydroelectric dams, power lines and opening of areas for mining (see Ferreira et al. 2014). Indeed, the Cachoeira do Tombo RPPN appears on the map of environmental conflicts for the state of Minas Gerais owing to the possible construction of a small hydroelectric dam (Zhouri 2014, GESTA 2015). The results of this study show that the area, which falls within the buffer zone of the Serra do Papagaio State Park, has a rich chiropterofauna. The buffer zones of protected areas in the Cerrado have also been shown to be used by medium and large-bodied mammals, including those which are conservation dependent (Paolino et al. 2016), though the importance of these zones for bats remains to be studied.

Further effort is still required to improve knowledge of the flora and fauna of each mountain chain of the Serra da Mantiqueira, where at least 37 species of bats have already been reported (Avila-Pires \& Gouveia 1977, Carvalho et al. 2013, Luz et al. 2013, Nobre et al. 2013a, Nobre et al. 2013b, Dias et al. 2015, Martins et al. 2015). The results of this study also further corroborate the importance of using mistnets at roosts to increase the probability of capturing the richness and abundance of insectivorous bats present in the area, especially when more sophisticated methods, such as audio-recording, are not available.

\section{Supplementary material}

The following online material is available for this article: Appendix 1

\section{Acknowledgments}

We thank Gilberto Ribeiro for the permits to work in RPPN Cachoeira do Tombo and we thank Adriano Senador and Jaqueline Senador for permission to work on their lands. We thank Ilda de Sá and Estalagem do Mirante for help with logistics and accommodation in the field. We thank Mayara A. Martins, Luciana M. Costa, Priscilla Peixoto, Sylvia Coelho, Egon Valle, Natália Lima, Thaisa Medeiros, Ayesha Pedrozo and Luís Gomes for their help in the field. We thank for Marcelo Nogueira for assisting in the identification of bats of the genus Eptesicus. WDC received a PhD scholarship from CAPES; BSX received a scholarship fund from FAPERJ and CELE received grants from FAPERJ (E-26/102.960/2012) and CNPq (Process 301061/20076 ). The present study was developed under a permit granted by IBAMA (Processes 1785/89-IBAMA and SISBIO 10356-1) and IEF (UC: 151/11 - Extension I). We are grateful to Karen Mustin for revising the English of this manuscript and the two reviewers for their helpful criticisms.

\section{Author contributions}

Bruna da Silva Xavier: substantial contribution in the concept and design of the study, data collection, analysis and interpretation, manuscript preparation and critical revision, adding intellectual content.

William Douglas Carvalho: substantial contribution in the concept and design of the study, data collection, analysis and interpretation, manuscript preparation and critical revision, adding intellectual content.
Daniela Dias: confirmation of identification of some of the bat vouchers; contribution to data analysis and interpretation, manuscript preparation and critical revision, adding intellectual content.

Lorena de Oliveira Tabosa: contribution to data collection and critical revision of the manuscript, adding intellectual content.

Carlos Eduardo Lopes Santos: contribution to data collection and critical revision of the manuscript, adding intellectual content.

Carlos Eduardo Lustosa Esbérard: substantial contribution in the concept and design of the study, data collection, analysis and interpretation, manuscript preparation and critical revision, adding intellectual content and providing financial resources.

\section{Conflicts of Interest}

The authors declare that they have no conflict of interest related to the publication of this manuscript.

\section{References}

ANDRADE, T.Y., THIES, W., ROGERI, P.K., KALKO, E.K.V. \& MELLO, M.A.R. 2013. Hierarchical fruit selection by Neotropical leaf-nosed bats (Chiroptera: Phyllostomidae). J. Mammal. 94(5):1094-1101.

ÁVILA-PIRES, F.D. \& GOUVEA, E. 1977. Mamíferos do Parque Nacional do Itatiaia. Bol. Mus. Nac., Zool. 291:1-29.

BERGALLO, H.G., ESBÉRARD, C.E.L., MELLO, M.A.R., LINS, V., MANGOLIN, R. \& BAPTISTA, M. 2003. Bat species richness in Atlantic Forest: What is the minimum sampling effort? Biotropica 35(2):278-288.

BONACCORSO, F.J. \& SMYTHE, N. 1972. Punch-marking bats: an alternative to banding. J. Mammal. 53(2):389-390.

BRITO, D., OLIVEIRA, L.C., OPREA, M. \& MELLO, M.A.R. 2009. An overview of the Brazilian mammalogy: trends, biases and future directions. Zoologia-Curitiba 26:67-73.

CAMPANHA, R.A.C. \& FOWLER, H.G. 1993. Roosting assemblages of bats in arenitic caves in remnant fragments of Atlantic Forest in southeastern Brazil. Biotropica 25(3):362-365.

CARVALHO, W.D. 2015. Influência da altitude na história de vida de morcegos Phyllostomidae (Chiroptera, Mammalia) na Floresta Atlântica. Tese de Doutorado. Universidade Federal Rural do Rio de Janeiro, Seropédica.

CARVALHO, W.D., MARTINS, M.A., DIAS, D. \& ESBÉRARD, C.E.L. 2013. Extension of geographic range, notes on taxonomy and roosting of Histiotus montanus (Chiroptera: Vespertilionidae) in southeastern Brazil. Mammalia 77(3):341-346.

COSTA, L.M. \& ESBÉRARD, C.E.L. 2011. Desmodus rotundus (Mammalia: Chiroptera) on the southern coast of Rio de Janeiro state, Brazil. Braz. J. Biol. 71(3):739-746.

COSTA, T.C.C., FIDALGO, E.C.C., SANTOS, R.F., ROCHA, J.V., METZGER, J.P., VICENS, R.S., TANIZAKI-FONSECA, K. \& BOHRER, C.B.A. 2009. Diversidade de paisagens no Estado do Rio de Janeiro. In Estratégias e ações para a conservação da Biodiversidade no Estado do Rio de Janeiro (H.G. Bergallo, E.C.C. Ficalgo, C.F.D. Rocha, M.C. Uzêda, M.B. Costa, M.A.S. Alves, M.V. Sluys, M.A. Santos, T.C.C. Costa \& A.C.R. Cozzolino, eds). Instituto Biomas, Rio de Janeiro, p.101-110.

COSTA, C.M.R., HERMANN, G., MARTINS, C.S., LINS, L.V. \& LAMAS, I. 1998. Biodiversidade em Minas Gerais: um atlas para sua conservação. Fundação Biodiversitas, Belo Horizonte.

COSTA, L.M., LUZ, J.L. \& ESBÉRARD, C.E.L. 2012. Riqueza de morcegos insetívoros em lagoas no Estado do Rio de Janeiro, Brasil. Pap. Avulsos de Zool. 52(2):7-19. 
DELCIELLOS, A.C., NOVAES, R.L.M., LOGUERCIO, M.F.C., GEISE, L., SANTORI, R.T., SOUZA, R.F., PAPI, B.S., RAÍCES, D.S.L., VIEIRA, N.R., FELIX, S., DETOGNE, N., SILVA, C.C.S., BERGALLO, H.G. \& ROCHA-BARBOSA, O. 2012. Mammals of Serra da Bocaina National Park, state of Rio de Janeiro, southeastern Brazil. Check List 8(4):675-692.

DIAS, D., ESBÉRARD, C.E.L. \& PERACCHI, A.L. 2008. Riqueza, diversidade de espécies e variação altitudinal de morcegos na Reserva Biológica do Tinguá, estado do Rio de Janeiro, Brasil (Mammalia, Chiroptera). In Ecologia de morcegos (N.R. REIS, A.L. PERACCHI \& G.A.D. SANTOS, eds.). Technical Books Editora, Rio de Janeiro, p. 125-142.

DIAS, D., CARVALHO, W.D., TEIXEIRA, T.S.M., TAVARES, D., XAVIER, B.S., VALLE, E.L.V. \& ESBÉRARD, C.E.L. 2015. First record of Myotis izecksohni (Chiroptera, Vespertilionidae) for the Atlantic Forest of Minas Gerais, southeastern Brazil. Mastozool. Neotrop. 22(1):149-153.

DRUMMOND, G.M., MARTINS, C.S., MACHADO, A.B.M., SEBAIO, F.A. \& ANTONINI, Y. 2005. Biodiversidade em Minas Gerais, um atlas para sua conservação. 2 ed. Fundação Biodiversitas, Belo Horizonte.

ESBÉRARD, C.E.L. 2007. Influence of moon cycle in phyllostomid bat capture. Iheringia, Zool. 97(1):81-85.

ESBÉRARD, C.E.L \& DAEMON, C. 1999. Novo método para marcação de morcegos. Chiropt. Neotrop. 5(1-2):116-117.

FERREIRA, J., ARAGÃO, L.E.O.C., BARLOW, J., BARRETO, P., BERENGUER, E., BUSTAMANTE, M., GARDNER, T.A., LEES, A.C., LIMA, A., LOUZADA, J., PARDINI, R., PARRY, L., PERES, C.A., POMPEU, P.S., TABARELLI, M. \& ZUANON, J. 2014. Brazil's environmental leadership at risk: Mining and dams threaten protected areas. Science 346:706-707.

GARBINO, G.S.T. 2011. Chiroptera, Emballonuridae, Saccopteryx leptura (Schreber, 1774): Range extension and first record for the states of São Paulo and Minas Gerais, southeastern Brazil. Check List 7(3):319-322.

GESTA - Grupo de Estudos em Temáticas Ambientais. Mapa dos conflitos ambientais de Minas Gerais. 2015. http://conflitosambientaismg.lcc.ufmg. br/observatorio-de-conflitos-ambientais/mapa-dos-conflitos-ambientais/ (último acesso em 31/10/2017).

GREGORIN, R. \& LOUREIRO, L.O. 2011. New records of bats for the state of Minas Gerais, with range extension of Eptesicus chiriquinus Thomas (Chiroptera: Vespertilionidae) to southeastern Brazil. Mammalia 75(3):291294.

GREGORIN, R., TAHARA, A.S. \& BUZZATO, D.F. 2011. Molossus aztecus and other small Molossus (Chiroptera: Molossidae) in Brazil. Acta Chiropterol. 13(2):311-317.

GREGORIN, R., VASCONCELLOS, K.L. \& GIL, B.B. 2015. Two new records of bats (Chiroptera: Phyllostomidae) for the Atlantic Forest, eastern Brazil. Mammalia 79(1):121-124.

GREGORIN, R., BERNARD, E., LOBÃO, K.W., OLIVEIRA, L.F., MACHADO, F.S., GIL, B.B. \& TAVARES, V.C. 2017. Vertical stratification in bat assemblages of the Atlantic Forest of South-eastern Brazil. J. Trop. Ecol. 33(5):299-308

GUIMARÃES, M.M. 2014. Morcegos cavernícolas do Brasil: composição, distribuição e serviços ambientais. Dissertação de Mestrado. Universidade Federal de Lavras, Lavras.

IBGE (Instituto Brasileiro de Geografia e Estatística). 2012. Manual técnico da vegetação brasileira: sistema fitogeográfico, inventário das formações florestais e campestres, técnicas e manejo de coleções botânicas, procedimentos para mapeamento, 2 ed. Ministério do Planejamento Orçamento e Gestão, Rio de Janeiro.

ICMBIO. 2014. Espécies ameaçadas. http://www.icmbio.gov.br/portal/ faunabrasileira/lista-de-especies (último acesso em 31/10/2017).

KALKO E.K.V., ESTRADA-VILLEGAS, S., WEGMANN, M.S.M. \& MEYER, C.F.J. 2008. Flying high: assessing the use of the aerosphere by bats. Integr. Comp. Biol. (1):1-14.

KUNZ, T.H \& PARSONS, S. 2009. Ecological and behavioural methods for the study of bats. The Johns Hopkins University Press, Baltimore.
LOUREIRO, L.O. 2014. Sistemática de Molossus (Mammalia: Chiroptera: Molossidae) com ênfase nas espécies ocorrendo no Brasil. Dissertação de Mestrado. Universidade Federal de Minas Gerais, Belo Horizonte.

LOURENÇO, E.C., COSTA, L.M., SILVA, R.M. \& ESBÉRARD, C.E.L. 2010. Bat diversity of Ilha da Marambaia, southern Rio de Janeiro State, Brazil (Chiroptera, Mammalia). Rev. Bras. Biol. 70(3):511-519.

LUZ, J.L., COSTA, L.M., JORDÃO-NOGUEIRA, T., ESBÉRARD, C.E.L. \& BERGALLO, H.G. 2013. Morcegos em área de Floresta Montana, Visconde de Mauá, Resende, Rio de Janeiro. Biota Neotrop. 13(2):190-195 http:// www.biotaneotropica.org.br/v13n2/en/abstract?inventory+bn02513022013 (último acesso em 31/10/2017).

MARQUES, J.T., RAMOS-PEREIRA, M.J. \& PALMEIRIM, J.M. 2016. Patterns in the use of rainforest vertical space by Neotropical aerial insectivorous bats: all the action is up in the canopy. Ecography 39(5):476-486.

MARTINS, M.A., CARVALHO, W.D., DIAS, D., FRANÇAS, D.S., OLIVEIRA, M.B. \& PERACCHI, A.L. 2015. Bat species richness (Mammalia, Chiroptera) along an elevational gradiente in the Atlantic Forest of Southeastern Brazil. Acta Chiropterol. 17(2):401-409.

MEYER, C.F., AGUIAR, L.M.S., AGUIRRE, L.F., BAUMGARTEN, J., CLARKE, F.M., COSSON, J.F., VILLEGAS, S.E., FAHR, J., FARIA, D., FUREY, N., HENRY, M., HODGKISON, R., JENKINS, R.K.B., JUNG, K.G., KINGSTON, T., KUNZ, T.H., GONZALEZ, M.C.M., MOYA, I., PATTERSON, B.D., PONS, J.M., RACEY, P.A., REX, K., SAMPAIO, E.M., SOLARI, S., STONER, K.E., VOIGT, C.C., STADEN, D., WEISE, C.D. \& KALKO, E.K.V. 2011. Accounting for detectability improves estimates of species richness in tropical bat surveys. J. Appl. Ecol. 48(3):777-787.

MITTERMEIER, R.A., GIL, R.P., HOFFMAN, M., PILGRIM, J., BROOKS, T., MITTERMEIER, C.G., LAMOREUX, J. \& FONSECA, G.A.B. 2005 Hotspots revisited: earth's biologically richest and most endangered terrestrial ecoregions, 2. ed. University of Chicago Press, Boston.

MODESTO, T.C., PESSÔA, F.S., ENRICI, M.C., ATTIAS, N., JORDÃONOGUEIRA, T., COSTA, L.M., ALBUQUERQUE, H.G. \& BERGALLO, H.G. 2008. Mamíferos do Parque Estadual do Desengano, Rio de Janeiro, Brasil. Biota Neotrop. 8(4):153-158 http://www.biotaneotropica.org.br/ v8n4/pt/abstract?article+bn01408042008 (último acesso em 31/10/2017).

MORAS, L.M, BERNARD, E. \& GREGORIN, R. 2013. Bat assemblages at a high altitude area in the Atlantic Forest of southeastern Brazil. Mastozool. Neotrop. 20:269-278.

MYERS, N., MITTERMEIER, R.A., MITTERMEIER, C.G., FONSECA, G.A.B. \& KENT, J. 2000. Biodiversity hotspots for conservation priorities. Nature 403:853-858.

NOBRE, P.H., MANHAES, M.A., BASTOS NETO, O.J., REZENDE, A.C., RODRIGUES, A.S. 2013a. Bat assemblages from montain forest areas in the Serra Negra region, southeastern Brazil. Mastozool. Neotrop. 20:279-287.

NOBRE, P.H., MELLO, R.M., MANHAES, M.A., REZENDE, A.C. 2013b. Morcegos (Chiroptera, Mammalia) do Parque Estadual do Ibitipoca, Minas Gerais - Brasil. MG.Biota 6(2):4-29.

OKSANEN, J., BLANCHET, F.G., FRIENDLY, M., KINDT, R., LEGENDRE, P., MCGLINN, D., MINCHIN, P.R., O'HARA, R.B., SIMPSON, G.L., SOLYMOS, P., STEVENS, M.H.H., SZOECS, E. \& WAGNER, H. 2017. Vegan: community ecology package. R package version $2.4-3$. https:// CRAN.R-project.org/package $=$ vegan

OLIVEIRA, L.F. 2013. Assembleia de Chiroptera (Mammalia) no Parque Estadual do Rio Doce, Minas Gerais: riqueza, composição e estratificação vertical. Dissertação de Mestrado, Universidade Federal de Juiz de Fora, Juiz de Fora.

PAOLINO, R.M., VERSIANI, N.F., SALVADOR, N.A.P., RODRIGUES, T.F., KREPSCHI, V.G. \& CHIARELLO, A.G. 2016. Buffer zone use by mammals in a Cerrado protected area. Biota Neotrop. 16(2):e20140117 http://dx.doi. org/10.1590/1676-0611-BN-2014-0117 (último acesso em 31/10/2017).

RADAM BRASIL. 1983. Levantamento de recursos naturais, v. 32, folha S/ F. 23/ 24. Rio de Janeiro/Vitória. Ministério das Minas e Energias, Rio de Janeiro.

R CORE TEAM 2017. R: A language and environment for statistical computing. R Foundation for Statistical Computing, Vienna, Austria. URL https:// www.R-project.org/. 
Xavier, B.S. et al.

REIS N.R., FREGONEZI, M.N., PERACCHI, A.L. \& SHIBATTA O.A. 2013. Morcegos do Brasil - Guia de Campo. Technical Books, Rio de Janeiro.

RIBEIRO, M.C., METZGER, J.P., MARTENSEN, A.C., PONZONI, F.J. \& HIROTA, M.M. 2009. The Brazilian Atlantic Forest: How much is left, and how is the remaining forest distributed? Implications for conservation. Biol. Conserv. 142:1141-1153.

SÁ-JÚNIOR, A., CARVALHO, L.G., SILVA, F.F. \& ALVES, M.C. 2012. Application of the Köppen classification for climatic zoning in the state of Minas Gerais, Brazil. Theor. Appl. Climatol. 108:1-7.

SCOLFORO, J.R.S., OLIVERIRA, A.D., DAVIDE, A.C. \& CAMOLESI, J.F. 2002. Manejo sustentável da candeia Eremanthus erythropappus e Eremanthus incanus: relatório técnico científico. Universidade Federal de Lavras, Lavras.
STEVENS, R.D. 2013. Gradients of bats diversity in Atlantic Forest of South America: environmental seasonality, sampling effort and spatial autocorrelation. Biotropica 45(6):764-770.

STRAUBE, F. \& G. BIANCONI. 2002. Sobre a grandeza e a unidade utilizada para estimar esforço de captura com utilização de redes-de-neblina. Chiropt. Neotrop. 8(1-2):150-152

TAVARES, V.C., AGUIAR, L.M.S., PERINI, F.A., FALCÃO, F.C. \& GREGORIN, R. 2010. Bats of the state of Minas Gerais, southeastern Brasil. Chiropt. Neotrop. 16(1):675-705.

TRAJANO, E. 1985. Ecologia de populações de morcegos cavernícolas em uma região cárstica do sudeste do Brasil. Rev. Bras. Zool. 2(5):255-320.

ZHOURI, A. 2014. Mapping environmental inequalities in Brazil: mining, environmental conflicts and impasses of mediation. desiguALdades.net Working Paper Series 75:2-39. 